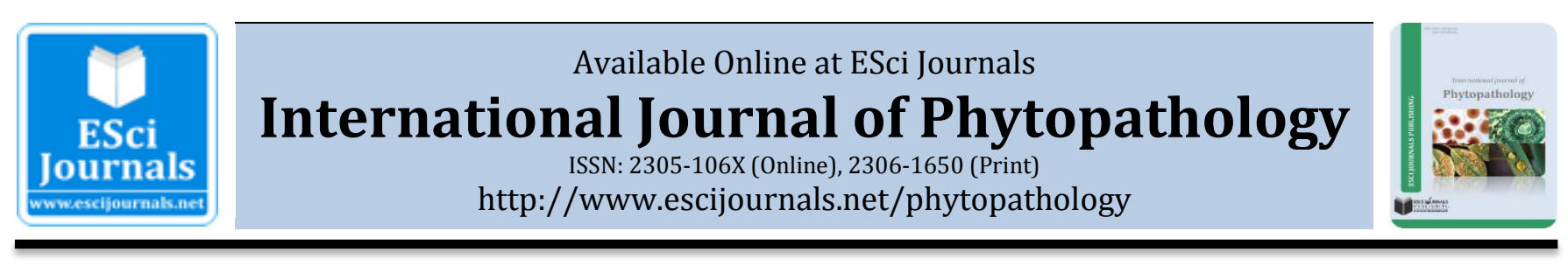

\title{
THE FIRST RECORD OF ALTERNARIA TRITICINA THE CAUSATIVE AGENT OF ALTERNARIA LEAF BLIGHT IN WHEAT AND BARLEY IN IRAQ
}

\author{
Mohammed W. Khudhair*, Hadi M. Aboud, Naeem S. Dheyab, Ali K. Shbar, Hiatham S. Khalaf \\ Integrated Pest Control Research Center, Agricultural Research Directorate, Ministry of Science and Technology, \\ Baghdad, Iraq.
}

\section{A B S T R A C T}

Alternaria leaf blight caused by Alternaria triticina can cause high yield losses at the severe infection in wheat and barley. It is first time for this pathogen to be recorded in Iraq. The investigation process of this disease included 25 locations from 12 sites in 5 provinces that plant wheat and barley in the south and middle of Iraq. The results revealed that the fungus was isolated from almost all examined locations with different frequency. Shethaif- Al Garbie and Sheikh Saad showed higher number of isolates with 60 and 40 in wheat fields, respectively; while, Shethaif- Al Garbie and Dabuni expressed the highest number of isolates in barley fields with 45 and 33, respectively. The highest isolation frequency in wheat fields was at Sheikh Saad and Ali Alsharqi with 100\% followed by Ali Algharbie with $90 \%$ and the lowest was at Al- Kut and Al-Huria with 37.5 and 40\%, respectively. The highest isolation frequency in barley fields was recorded at Dabuni with $82.5 \%$ followed by Shethaif- Al Garbie and Babil / Al-Huria with $75 \%$ and the lowest was at Al-Basrah/ Shatt al-Arab with $20 \%$. The fungus was isolated from all plant parts (stem, leaf, and spike); however, spikes recorded the highest isolation frequency reaching $100 \%$ in some locations.

Keywords: Alternaria triticina, Alternaria leaf blight, wheat and barley.

\section{INTRODUCTION}

Wheat (Triticum aestivum) and barley (Hordeum vulgare L.) are the first and second crops in Iraq. Iraq produces about 3 million tons of wheat and 900,000 tons of barley annually according to FAO GIEWS, 2014. However, Iraq imports 1.7 million tons of wheat each year to cover people need. Iraq plants about 1,625 million hectares of wheat according to the Ministry of Agriculture statistics expressing the importance of this crop. A. triticina first recorded in India and it causes high yield losses in wheat and barley (Prasada and Prabhu, 1962). The fungus was also reported from Argentina, China, Turkey, Egypt, Greece, France, Lebanon, Nigeria, Middle East, Italy, Bangladesh, Mexico, and North Africa (Perelló and Sisterna, 2006, Özçelik and Özçelik, 1997, Beshir, 1994, Logrieco et al., 1990, Wiese, 1987, Frisullo, 1982, Waller, 1981, Anahosur, 1978, Wiese, 1977). In the severe infection yield losses may reach about $60 \%$

\section{* Corresponding Author:}

Email: mohammedwaleed74@yahoo.com

(C) 2014 ESci Journals Publishing. All rights reserved. of the planted area (Prabhu and Singh, 1974, Sokhi, 1974). It can cause significant decrease in seeds weight (Raut et al., 1983).

This pathogen is considered as a soil borne and seed borne; however, soil borne does not play an active role in fungal transmission under hot conditions(Kumar and Arya, 1973, Kumar and Rao, 1979). Seeds can carry out the pathogen as conidia on the surface or as a mycelium inside the seed providing inoculums for the next season (Kumar and Arya, 1973, Kumar and Arya, 1976). It is difficult to distinguish $A$. triticina from other Alternaria species and it always a matter of confusion due to the close morphological characteristics despite of the developed recent studies (Dugan and Peever, 2002).

The main objective of this study is to investigate the occurrence and distribution of A. triticina in wheat and barley fields during growing season in the south and middle of Iraq.

\section{MATERIALS AND METHODS}

Samples Collection: Samples were collected from wheat and barley fields in the middle and south of Iraq particularly provinces that planting cereals from 
following sites (Al-Numaniyah, Kut, Dabuni, Shethaif- Al Garbie, Sheikh Saad, Amarah, Ali Algharbie, Kumayt, Ali Alsharqi, Al Diwaniyah, Shatt al-Arab, Al-Huria). Over 500 samples were collected from 12 sites from specific points according to Global Positioning System (GPS) during wheat seasons covering 5 Iraqi provinces in the middle and south (Table 1). Samples were gathered according to the targeted area and cereal type (wheat or barley). Generally, wheat is more popular in Iraq than barley; therefore, wheat fields are larger than barley ones which explain the higher number of wheat samples. Fungal Isolation and Purification: Three $2 \mathrm{~mm}$ pieces of tissue from each stem, leaf and spike were subjected to fungal isolation. The pieces were surface sterilized in bleach ( $1 \%$ available chlorine) for 5 minutes, and washed twice in sterile water for 5 minutes. Then, the pieces were dried by placing them on sterile paper towel. Subsequently, tissue pieces were transferred onto quarter-strength potato dextrose agar (PDA) plates which contain $100 \mu \mathrm{g} / \mathrm{ml}$ streptomycin sulphate and 10 $\mu \mathrm{g} / \mathrm{ml}$ tetracycline hydrochloride. Plates were incubated at ambient temperature and placed under standard Table 1. Collected samples from different locations of midd white fluorescent light (35098 F18E/33 General Electric, USA) for 24 hours for $5-7$ days. Spore suspension was made by adding 3-4 drops of sterile distilled water on the fungal colony that were grown around the plated wheat tissues using sterile flame-sterilized loop. This spore suspension was streaked onto $2 \%$ water agar media by using a flame-sterilized metal loop and plates were incubated under laboratory conditions for $24 \mathrm{~h}$. A single germinated conidium was transferred onto fullstrength PDA media plate and incubated at ambient temperature according to Scott and Chakraborty (2010).

Alternaria triticina Identification: Alternaria isolates were identified according to (Prasada and Prabhu, 1962, Dugan and Peever, 2002, Mercado Vergnes et al., 2006, Simmons, 2007). Isolates obtained from different plant parts (leaf, stem, and spike) from wheat and barley at the end of season. There is a clear overlap between $A$. triticina that causes Alternaria leaf blight and $A$. alternata that causes black mold on wheat especially the symptoms were discovered just before harvesting stage and the fungus was isolated from different plants parts (leaf, stem, and seeds).

\begin{tabular}{llcccc}
\hline \multicolumn{1}{c}{ Province } & \multicolumn{1}{c}{ Site } & Longitude & Latitude & Locations & Samples \\
\hline \multirow{2}{*}{ Wasit } & Al-Numaniyah & $45^{\circ} 24^{\prime} \mathrm{E}$ & $32^{\circ} 35^{\prime} \mathrm{N}$ & 2 & 40 \\
& Kut & $45^{\circ} 49^{\prime} \mathrm{E}$ & $32^{\circ} 30^{\prime} \mathrm{N}$ & 1 & 33 \\
& Dabuni & $45^{\circ} 21^{\prime} \mathrm{E}$ & $32^{\circ} 21^{\prime} \mathrm{N}$ & 3 & 60 \\
& Shethaif- Al Garbie & $45^{\circ} 11^{\prime} \mathrm{E}$ & $32^{\circ} 87^{\prime} \mathrm{N}$ & 3 & 144 \\
& Sheikh Saad & $46^{\circ} 12^{\prime} \mathrm{E}$ & $32^{\circ} 66^{\prime} \mathrm{N}$ & 3 & 85 \\
\hline Amarah & Amarah & $46^{\circ} 69^{\prime} \mathrm{E}$ & $31^{\circ} 26^{\prime} \mathrm{N}$ & 1 & 22 \\
& Ali Algharbie & $46^{\circ} 66^{\prime} \mathrm{E}$ & $32^{\circ} 49^{\prime} \mathrm{N}$ & 2 & 35 \\
& Kumayt & $46^{\circ} 94^{\prime} \mathrm{E}$ & $32^{\circ} 10^{\prime} \mathrm{N}$ & 3 & 56 \\
& Ali Alsharqi & $46^{\circ} 43^{\prime} \mathrm{E}$ & $32^{\circ} 70^{\prime} \mathrm{N}$ & 2 & 40 \\
\hline Al-Qadisiyyah & Al Diwaniyah & $44^{\circ} 55^{\prime} \mathrm{E}$ & $31^{\circ} 59^{\prime} \mathrm{N}$ & 2 & 44 \\
\hline Al-Basrah & Shatt al-Arab & $47^{\circ} 77^{\prime} \mathrm{E}$ & $30^{\circ} 44^{\prime} \mathrm{N}$ & 2 & 45 \\
\hline Babil & Al-Huria & $44^{\circ} 39^{\prime} \mathrm{E}$ & $32^{\circ} 84^{\prime} \mathrm{N}$ & 1 & 52 \\
\hline
\end{tabular}
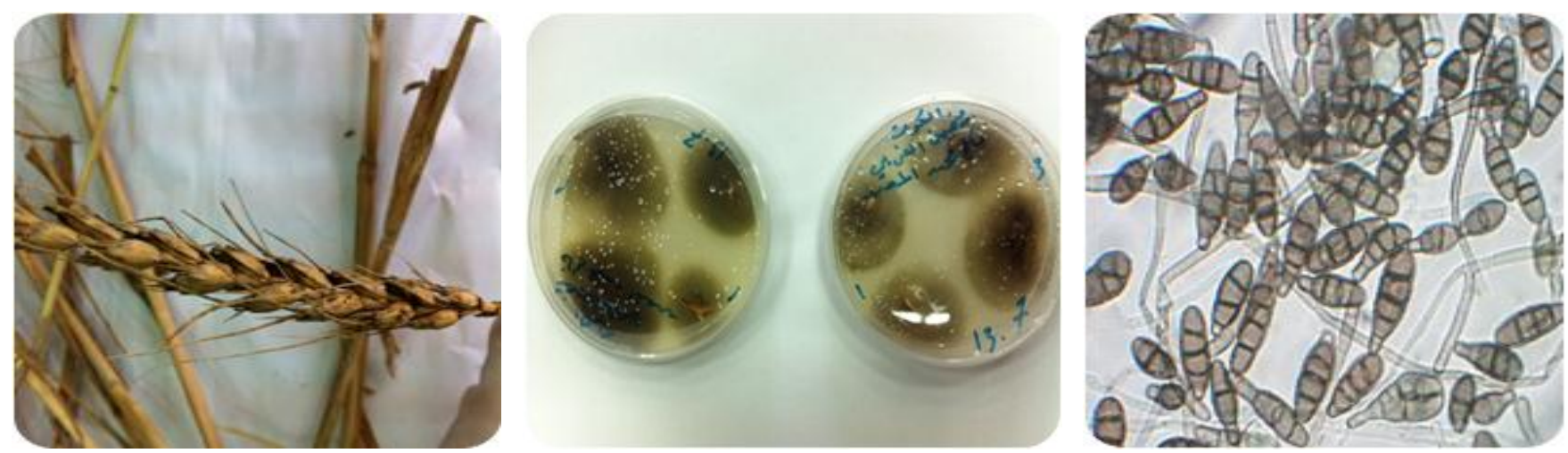

Figure 1. a. Alternaria leaf blight symptoms on stems and spikes b. A. triticina colony shape and color on PDA medium c. A. triticina young conidia and mycelia shape and color. 


\section{RESULTS}

Morphological characteristics of the fungus such as mycelium shape and color; conidium shape, color, and size; and conidiophores shape, were used to identify the exact causative Alternaria species. Mycelia and conidiophores are spetated, brunched, and have the same color. Mycelium width is $2-7 \mu \mathrm{m}$. The conidia vary in length from 17-85 × 7.5 -29, $15.8-68 \times 7-13.5$ and $18-$ $88 \times 7-18 \mu \mathrm{m}$ on malt extract agar, standard nutrient agar, and the host, respectively (Prabhu and Prasada, 1970). A triticina produce black to brown colored colony on PDA medium reaching $80 \mathrm{~mm}$ after five days at $25^{\circ} \mathrm{C}$.

Samples were collected from randomly chose wheat fields and the number of samples was determined according to the planted area. Some province sites revealed high number of isolates in wheat fields such as Shethaif- Al Garbie and Sheikh Saad in Wasit with 60 and Table 2. Number of examined samples and the percentage

\begin{tabular}{lccc}
\multicolumn{4}{c}{ Lable 2. Number of examined samples and the percentage of isolation frequency from wheat fields. } \\
\hline Wasit/Shethaif- Al Garbie & No. of examined samples & No. of Isolates & \% Isolation frequency \\
Wasit/Al- Kut & 80 & 60 & 75 \\
Wasit/Sheikh Saad & 16 & 6 & 37.5 \\
Wasit/ Al-Numaniyah & 40 & 40 & 100 \\
Dabuni & 25 & 12 & 48 \\
Al-Qadisiyyah/ Al Diwaniyah/Dahghar & 40 & 33 & 82.5 \\
Babil / Al-Huria & 40 & 20 & 50 \\
Amarah/ Kumayt & 30 & 12 & 40 \\
Amarah/ Ali Algharbie & 24 & 18 & 75 \\
Amarah/ Ali Alsharqi & 20 & 18 & 90 \\
Al-Basrah/ Shatt al-Arab & 16 & 16 & 100 \\
Table 3. Number of examined samples and the percentage of isolation frequency from barley fields. & 77.2 \\
\hline \multicolumn{1}{c}{ Location } & No. of examined samples & No. of Isolates & $\%$ Isolation \\
\hline Wasit/Shethaif- Al Garbie & 60 & 45 & 75 \\
Wasit/Sheikh Saad & 22 & 16 & 72.72 \\
Dabuni & 40 & 33 & 82.5 \\
Babil / Al-Huria & 20 & 15 & 75 \\
Amarah/ Kumayt & 22 & 15 & 68.18 \\
Amarah/ Ali Algharbie & 16 & 8 & 50 \\
Amarah/ Ali Alsharqi & 16 & 12 & 75 \\
Al-Basrah/ Shatt al-Arab & 10 & 2 & 20 \\
\hline
\end{tabular}

A. triticina isolates were collected from different plant parts (stem, leaf, and spike). The distribution of isolates among plant parts showed that spike recorded the highest isolation frequency rate at all locations and samples as compared to other tested parts (Table 4). AlQadisiyyah/ Al Diwaniyah-Dahghar and Al-Basrah/ Shatt
40 isolates respectively (Table 2). However, some locations expressed high isolation frequency such as Sheikh Saad and Ali eastern with $100 \%$ followed by Ali Algharbie with 90\%. Dabuni, Shatt al-Arab, Shethaif- Al Garbie, and Kumayt showed high isolation frequency ranging from $82.5-75 \%$. The lowest isolation frequency rate was recorded at Al- Kut and Al-Huria with 37.5 and $40 \%$ respectively (Table 2 ).

Wasit in Shethaif- Al Garbie and Dabuni showed the highest number of isolates in barley fields with 45 and 33 , respectively (Table 3 ). The highest isolation frequency rate was recorded at Dabuni with 82.5\% followed by Shethaif- Al Garbie and Babil / Al-Huria with $75 \%$. The lowest isolation frequency rate was reported at Al-Basrah/ Shatt al-Arab with 20\% (Table 3). Low number of locations of barley fields was examined to determine fungal isolation frequency due to the less planted area.

of isolation frequency from wheat fields. 
frequency especially at Wasit/ Kut and Wasit/ AlNumaniyah with $33.33 \%$ followed by Amarah/ Ali Alsharqi and Wasit/ Shethaif- Al Garbie with 25 and
$21.66 \%$ respectively. Leaf highest isolation frequency was recorded from Amarah/ Kumayt with 33.33\% followed by Dabuni with $18.18 \%$ (Table 4).

Table 4. The distribution of fungal isolates according to plant part (stem, leaf, and spike) in wheat fields.

\begin{tabular}{lcccc}
\hline \multirow{2}{*}{ Location } & \multirow{2}{*}{ Number of isolates } & \multicolumn{3}{c}{ Plant part } \\
\cline { 3 - 5 } & & Stem $\%$ & Leaf\% & Spike\% \\
\hline Wasit/ Shethaif- Al Garbie & 60 & 21.66 & 13.33 & 65 \\
Wasit/ Kut & 6 & 33.33 & 0 & 66.66 \\
Wasit/Sheikh Saad & 40 & 20 & 10 & 70 \\
Wasit/ Al Numaniyah & 12 & 33.33 & 16.66 & 50 \\
Dabuni & 33 & 0 & 18.18 & 81.81 \\
Al-Qadisiyyah/ Al Diwaniyah/Dahghar & 20 & 0 & 0 & 100 \\
Babil / Al-Huria & 12 & 16.66 & 25 & 58.33 \\
Amarah/ Kumayt & 18 & 0 & 33.33 & 66.66 \\
Amarah/ Ali Algharbie & 18 & 0 & 11.11 & 88.88 \\
Amarah/ Ali Alsharqi & 16 & 25 & 12.5 & 62.5 \\
Al-Basrah/ Shatt al Arab & 17 & 0 & 0 & 100 \\
\hline
\end{tabular}

Barley isolates revealed almost the same trend as wheat ones with highest isolation frequency from spikes (Table 5). The highest isolation frequency rate was from spike at Dabuni, Amarah/ Kumayt, and AlBasrah/ Shatt al-Arab with $100 \%$ followed by Amarah/ Ali Algharbie, Amarah/ Ali Alsharqi, and Wasit/Sheikh Saad with 81.25, 68.75, and 68.18\% respectively. Stem highest frequency isolates was at Wasit/ Shethaif- Al Garbie with 35.48 followed by Babil / Al-Huria with 15\%. The highest rate of leaf isolates was at Babil / Al-Huria with $25 \%$ followed by Wasit/ Shethaif- Al Garbie with $24.19 \%$. Some of plant parts such as leaf and stem did not express fungal isolates (Table 5).

Table 5. The distribution of fungal isolates according to plant part (stem, leaf, and spike) in barley fields.

\begin{tabular}{lcccc}
\hline \multirow{2}{*}{ Location } & \multirow{2}{*}{ Number of isolates } & \multicolumn{3}{c}{ Plant part } \\
\cline { 3 - 5 } & & Stem & Leaf & Spike \\
\hline Wasit/ Shethaif- Al Garbie & 62 & 35.48 & 24.19 & 40.32 \\
Wasit/Sheikh Saad & 22 & 13.63 & 18.18 & 68.18 \\
Dabuni & 40 & 0 & 0 & 100 \\
Babil / Al-Huria & 20 & 15 & 25 & 60 \\
Amarah/ Kumayt & 22 & 0 & 0 & 100 \\
Amarah/ Ali Algharbie & 16 & 0 & 18.75 & 81.25 \\
Amarah/ Ali Alsharqi & 16 & 12.5 & 18.75 & 68.75 \\
Al-Basrah/ Shatt al Arab & 10 & 0 & 0 & 100 \\
\hline
\end{tabular}

\section{DISCUSSION}

This is first time for the fungus $A$. triticina to be recorded in wheat and barley fields in Iraq causing leaf blight. The olive-buff symptoms were noticed on wheat and barley leaves in the Iraqi middle and south fields especially at the mature stage. After first isolation of the fungus a larger screening was initiated to estimate infection distribution and density. The fungus was isolated from almost all the inspected fields and from all plant parts (stem, leaf, and spike); however, the infection severity varied from province to another and from location to another.
The emergence of this pathogen in Iraq might be because of the change in climate in the last three years with the increase of late rain during the planting season providing favorable conditions. Perelló and Sisterna (2006) also suggested the same reasons when A. triticina first recorded in Argentina. Moreover, agriculture practices such as conservation tillage, nitrogen fertilization, irrigation may increase this disease severity (Perelló and Sisterna, 2006). Another important explanation to the emergence of $A$. triticina is the use of seeds that were not certificated by Iraqi 
Ministry of Agriculture as Iraq Ministry of Agriculture normally does not allow farmers to plant unauthenticated wheat and barley seeds. Seeds can transmit this pathogen via the surface inoculation by conidia or via grown mycelia inside the seeds (Kumar and Arya, 1973, Kumar and Arya, 1976).

Another justification of the emergence of this disease is: it might be existed before but it was not recognizable due to the low infection rate because of the unfavorable climate conditions. Nevertheless, when the weather became favor to the pathogen, it turns out to be a pest that can cause remarkable yield losses. As in Argentina A. triticina reported in (1992) by Perelló et al but it emerged as a big problem on wheat by 2006 and one of the expected reasons was suitable weather conditions (Perelló and Sisterna, 2006). Wider studies on this pathogen should be established measuring the expected yield losses and host reaction. Moreover, it is important to investigate other Iraqi provinces particularly the north of Iraq to know the distribution of the pathogen and it is reaction to climate change.

\section{ACKNOWLEDGEMENT}

Authors acknowledge the all different support by the administration of Agricultural Research DirectorateIraqi Ministry of Science and Technology and IPM Center. Acknowledgment also express to Dr. Ayad Altaweel, Dr. Mohammed Z. Khalaf, and Dr. Hussain F. Al Rubeai for their support. Also authors acknowledge Rassoul Ali, Omar Mahmood, Nadia Jassim, and Bushra Hamza, for their assistance.

\section{REFERENCES}

Anahosur, K., 1978. Alternaria triticina.[Descriptions of Fungi and Bacteria]. IMI Descriptions of Fungi and Bacteria.

Beshir, M., 1994. Susceptibility of some wheat cultivars to Alternaria triticina and the biochemical changes associated with infection. Annals of Agricultural Science, Moshtohor. 32: 899-909.

Dugan, F. M. and T. L. Peever, 2002. Morphological and cultural differentiation of described species of Alternaria from Poaceae. Mycotaxon. 83: 229-64.

Frisullo, S., 1982. Parassiti fungini delle piante nell'Italia meridionale. 1: Alternaria triticina Pras. et Prab. $\mathrm{su}$ frumento duro [Triticum durum]. Phytopathologia Mediterranea.

Kumar, C. and A. Rao, 1979. Survival of Alternaria triticina, incitant of leaf blight of wheat. Current Science. 48: 869-70.
Kumar, V. and H. Arya, 1973. Certain aspects of perpetuation and recurrence of leaf blight of wheat in Rajasthan. Indian journal of mycology and plant pathology. 3: 93-4.

Kumar, V. and H. Arya, 1976. Ecology of Alternaria triticina causing leaf blight of wheat. Geobios. 3: 79.

Logrieco, A. and A. Bottalico and M. Solfrizzo and G. Mule, 1990. Incidence of Alternaria species in grains from Mediterranean countries and their ability to produce mycotoxins. Mycologia. 501-5.

Mercado Vergnes, D. and M. E. Renard and E. Duveiller and H. Maraite, 2006. Identification of Alternaria spp. on wheat by pathogenicity assays and sequencing. Plant Pathology. 55: 485-93.

ÖzçElik, N. and S. ÖzçElik, 1997. Investigations on some factors and strains affecting the production of Alternaria-toxins by a thin layer chromatographic method. Turkish Journal of Agriculture \& Forestry. 21: 1-5.

Perelló, A. and C. Cordo and H. Alippi, 1992. Tizón de la hoja del trigo ocasionado por Alternaria triticina Pras. \& Prab. en Sud América. Proceedings of the VIII Jornadas Fitosanitarias Argentinas.

Perelló, A. and M. Sisterna, 2006. Leaf blight of wheat caused by Alternaria triticina in Argentina. Plant Pathology. 55: 303-.

Prabhu, A. and R. Prasada, 1970. Investigations on the leaf blight disease of wheat caused by Alternaria triticina. Indian Phytopathology. 23: 19-27.

Prabhu, A. and A. Singh, 1974. Appraisal of yield loss in wheat due to foliage diseases caused by Alternaria triticina and Helminthosporium sativum. Indian Phytopathology. 27: 632-4.

Prasada, R. and A. Prabhu, 1962. Leaf blight of Wheat caused by a new species of Alternaria. Indian Phytopathology. 15: 292-3.

Raut, J. and S. Guldhe and P. Wangikar, 1983. Seed-borne infection of Alternaria triticina in wheat and its control. Indian Phytopathology. 36: 274-7.

Scott, J. B. and S. Chakraborty, 2010. Genotypic diversity in Fusarium pseudograminearum populations in Australian wheat fields. Plant Pathology. 59: 33847.

Simmons, E. G., 2007. Alternaria : an identification manual : fully illustrated and with catalogue raisonné 1796-2007. Utrecht, The Netherlands: CBS Fungal Biodiversity Centre. 
Int. J. Phytopathol. 03 (03) 2014. 133-138

Sokhi, S., 1974. Alternaria blight on wheat in India. PANS Pest Articles \& News Summaries. 20: 55-7.

Waller, J., 1981. The recent spread of some tropical plant diseases. International Journal of Pest Management. 27: 360-2.
Wiese, M., 1987. Compendium of wheat diseases. Disease compendium series.

Wiese, M. V., 1977. Compendium of wheat diseases. American Phytopathological Society. 